\title{
In Silico Inhibition Studies of Jun-Fos-DNA Complex Formation by Curcumin Derivatives
}

\author{
Anil Kumar' ${ }^{1}$ and Utpal Bora ${ }^{1,2}$ \\ ${ }^{1}$ Computational Biology Laboratory, Department of Biotechnology, Indian Institute of Technology Guwahati, Assam, \\ Guwahati 781039, India \\ ${ }^{2}$ Biotech Hub, Centre for the Environment, Indian Institute of Technology Guwahati, Assam, Guwahati 781039, India
}

Correspondence should be addressed to Utpal Bora, ubora@iitg.ernet.in

Received 28 August 2012; Revised 15 November 2012; Accepted 15 November 2012

Academic Editor: Armando Rossello

Copyright (C) 2012 A. Kumar and U. Bora. This is an open access article distributed under the Creative Commons Attribution License, which permits unrestricted use, distribution, and reproduction in any medium, provided the original work is properly cited.

Activator protein-1 (AP1) is a transcription factor that consists of the Jun and Fos family proteins. It regulates gene expression in response to a variety of stimuli and controls cellular processes including proliferation, transformation, inflammation, and innate immune responses. AP1 binds specifically to 12-O-tetradecanoylphorbol-13-acetate (TPA) responsive element 5' -TGAG/CTCA-3' (AP1 site). It has been found constitutively active in breast, ovarian, cervical, and lung cancers. Numerous studies have shown that inhibition of AP1 could be a promising strategy for cancer therapeutic applications. The present in silico study provides insights into the inhibition of Jun-Fos-DNA complex formation by curcumin derivatives. These derivatives interact with the amino acid residues like Arg155 and Arg158 which play a key role in binding of Jun-Fos complex to DNA (AP1 site). Ala151, Ala275, Leu283, and Ile286 were the residues present at binding site which could contribute to hydrophobic contacts with inhibitor molecules. Curcumin sulphate was predicted to be the most potent inhibitor amongst all the natural curcumin derivatives docked.

\section{Introduction}

Activator protein-1 (AP1) is a transcription factor that consists of either homo- or heterodimers of the Jun and Fos family proteins [1]. It regulates gene expression in response to a variety of stimuli, including environmental stresses, UV radiation, cytokines, and growth factors. AP1 in turn controls a number of cellular processes including proliferation, transformation, inflammation, and innate immune response. The Jun and Fos proteins share similar amino acid sequences that comprise the basic DNA-binding sequence and the adjacent leucine zipper region by which these proteins dimerize [2-4]. The AP1 transcription factor binds specifically to 12 -O-tetradecanoylphorbol-13-acetate (TPA) responsive element $5^{\prime}$-TGAG/CTCA- $3^{\prime}$ which is commonly referred to as the AP1 site $[5,6]$. C-fos and $c$-jun genes are autoregulated; the transcription of $c$-jun is stimulated by its own product, and in contrast $c$-fos is negatively autoregulated [7-9]. AP1 has been found constitutively active in many cancers including breast, ovarian, cervical, and lung. Numerous studies have shown that inhibition of AP1 has a profound effect on the behavior of cancer cells and tumors suggesting that AP1 could be a promising target for cancer therapy [10].

Curcumin, a dietary spice derived from the plant Turmeric (Curcuma longa), is used as a traditional medicine for inflammatory conditions [11]. Further, curcumin has been reported to have anti-inflammatory, anti-oxidant, and anticancer effects [12-15]. In vivo administration of curcumin was found to reduce the incidence and size of tumors in mice [16-19]. Moreover, curcumin was reported to inhibit proliferation and cell cycle progression in cancer cells [20]. Curcumin suppresses constitutive AP1 activity in HL-60, Raji, and prostate cancer cell lines (LNCaP, PC3 , and DU145) [21-25]. Curcumin was also reported to suppress LPS-induced cyclooxygenase- 2 gene expression by inhibiting AP1 DNA binding in BV2 microglial cells [26]. It was confirmed that curcumin directly interacts with JunFos dimer and inhibits its binding to DNA (AP1 site) [27]. Some synthetic curcumin derivatives have been discovered 
<smiles>CC(C)=CC(=O)CC(C)C1C=CC(C)=CC1</smiles><smiles>C=C1C=CC(C(C)CC(=O)C=C(C)C)C=C1</smiles><smiles>COc1cc(CCC(=O)C=C(O)CCc2ccc(O)c(OC)c2)ccc1O</smiles>
Tetrahydrocurcumin<smiles>COc1cc(/C=C/C(=O)/C=C(O)/C=C/c2ccc(O)c(OC)c2)ccc1[O-]</smiles>
Curcumin sulphate<smiles>COc1cc(/C=C/C(=O)CC(=O)/C=C/c2ccc(O)c(OC)c2)ccc1O</smiles><smiles>COc1cc(/C=C/C(=O)/C=C(O)/C=C/c2ccc(O)c(OC)c2)ccc1O</smiles><smiles>O=C(/C=C(O)/C=C/c1ccc(O)cc1)/C=C/c1ccc(O)cc1</smiles><smiles>COc1cc(CCC(=O)CC(O)CCc2ccc(O)c(OC)c2)ccc1O</smiles>
Hexahydrocurcumin<smiles>COc1ccc(CCC2=CC(=O)CC(c3ccc(OC)c(O)c3)O2)cc1O</smiles>

Cyclocurcumin<smiles>COc1cc(/C=C/C(O)=C/C(=O)/C=C/c2ccc(O)cc2)ccc1O</smiles><smiles>COc1cc(CCC(O)CC(O)CCc2ccc(O)c(OC)c2)ccc1O</smiles><smiles>COc1cc(/C=C/C(O)=C/C(=O)/C=C/c2ccc(OC3OC(C(=O)O)C(O)C(O)C3O)c(OC)c2)ccc1O</smiles>

FIGURE 1: Chemical structures of natural curcumin derivatives.<smiles>Oc1ccc(/C=C/c2cc(O)cc(O)c2)cc1</smiles>

Resveratrol<smiles>COc1cc(C[C@@H](C)[C@H](C)Cc2ccc(O)c(OC)c2)ccc1O</smiles>

Dihydroguaiaretic acid<smiles>N=C(O)c1ccc(COc2ccc(C(=O)c3ccc(OC4CCCC4)cc3O)cc2CCC(=O)O)cc1O</smiles>

T5224

FIgURE 2: Known inhibitors of Jun-Fos-DNA complex formation used in the study.

as inhibitors of Jun-Fos-DNA complex formation [2830]. However, no information on the site of interaction is reported yet. In the present study we investigate the interaction of curcumin derivatives with Jun-Fos complex by molecular docking studies.

\section{Methodology}

To investigate the interaction with Jun-Fos complex, curcumin natural derivatives (Figure 1), synthetic curcuminbased inhibitors (Table 1), and other known inhibitors of Jun-Fos-DNA complex formation (Figure 2) were drawn and 3D optimized using MarvinSketch (Free Academic License) and saved in Protein Data Bank (PDB) file format [31]. These molecules were prepared for molecular docking by merging nonpolar hydrogens, assigning Gastegier charges, and saving them in PDBQT file format using AutoDock Tools (ADT) 1.5.6 [32]. X-ray crystal structure of Jun-Fos-DNA complex (PDB ID: FOS1) was obtained from the Protein Data Bank (http://www.rcsb.org/pdb). For molecular docking DNA and other heteroatoms (water, ions, etc.) were removed using
PyMOL 0.99. Gasteiger charges were assigned, and Jun-Fos complex was saved in PDBQT file format using ADT.

Grid and docking parameter files were prepared using ADT, and molecular docking was performed with AutoDock 4.2.1 (Scripps Research Institute, USA) considering all the rotatable bonds of curcumin derivatives as rotatable and JunFos complex as rigid [33]. Grid box size of $90 \times 90 \times 90 \AA$ with $0.375 \AA$ spacing was selected that include the whole basic DNA-binding sequence and the adjacent leucine zipper region of Jun-Fos complex. Empirical-free energy function and Lamarckian genetic algorithm, with an initial population of 150 randomly placed individuals, a maximum number of $2,500,000$ energy evaluations, a mutation rate of 0.02 , and a crossover rate of 0.80 , were used to perform molecular docking. Hundred independent docking runs were performed for each molecule. Curcumin derivative-Jun-Fos complex for lowest free energy of binding $(\Delta G)$ confirmation from the largest cluster was written in PDBQT format and converted to PDB file format using UCSF Chimera 1.6.1. Further, these complexes were analyzed using PyMOL 0.99 for possible polar and hydrophobic interactions. All the docking studies were performed at Intel(R) Xeon(R) CPU (3.2 GHz) with Linux-based operating system Fedora 15. 


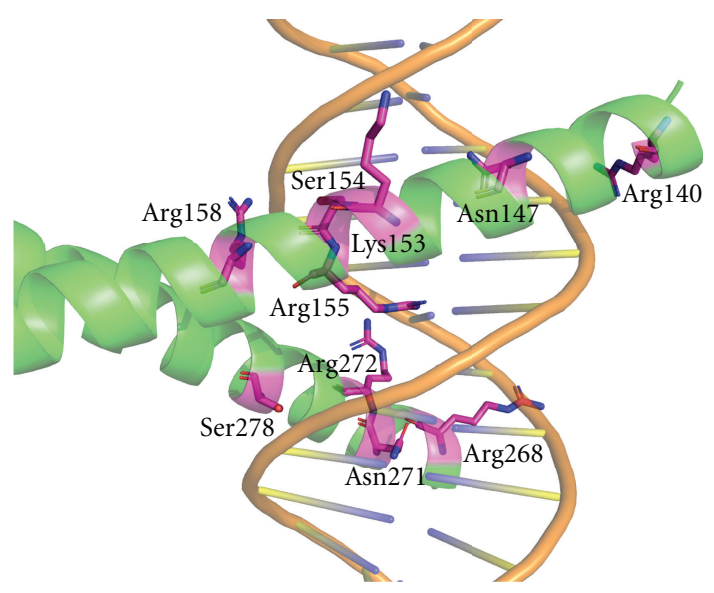

FIGURE 3: X-ray crystal structure of Jun-Fos-DNA complex (PDB ID: FOS1) showing amino acid residues (magenta) which form hydrogen bond with DNA (AP1 site).

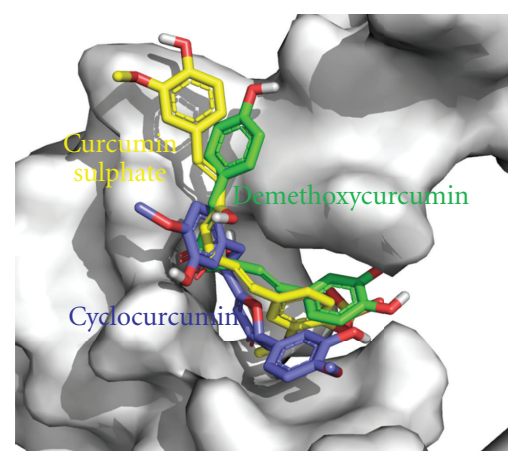

(a)

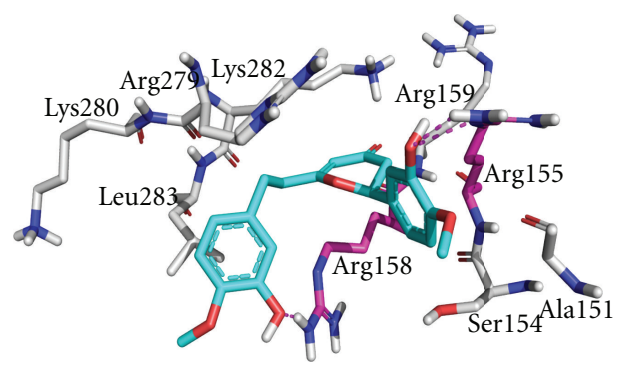

(c)

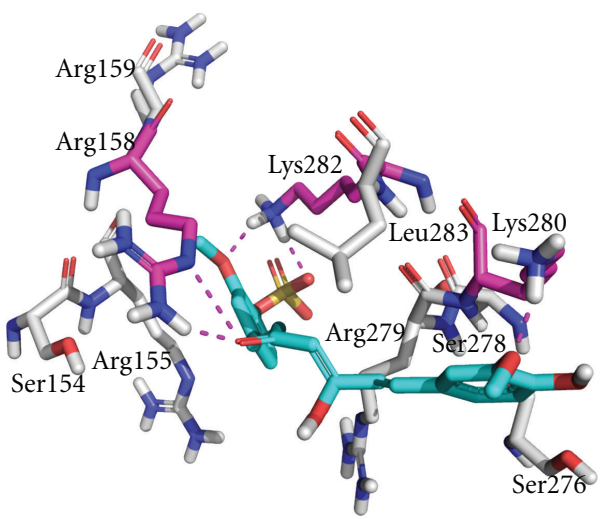

(b)

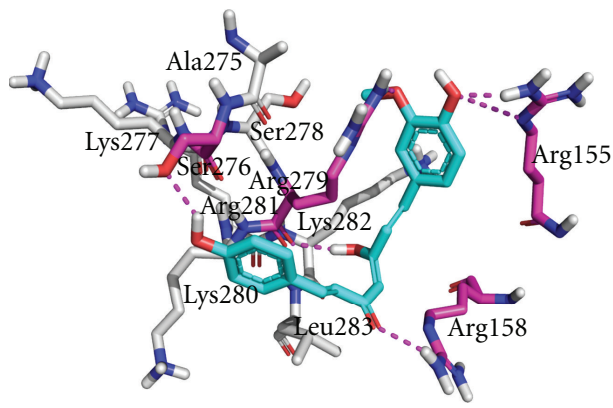

(d)

Figure 4: Binding modes of natural curcumin derivatives. (a) Curcumin sulphate (yellow), cyclocurcumin (blue), and demethoxycurcumin (green) docked to DBR of Jun-Fos complex; (b) curcumin sulphate (cyan) showing polar contacts with Arg158, Lys280, and Lys282 (magenta) (c) cyclocurcumin showing polar contacts with Arg155 and Arg158 (magenta); (d) demethoxycurcumin showing polar contacts with Arg155, Arg158, Ser276, and Arg279 (magenta).

\section{Results and Discussions}

X-ray crystal structure of Jun-Fos-DNA complex shows that Arg140, Asn147, Lys153, Ser154, Arg155, Arg158, Arg268, Asn271, Arg272, and Ser278 are the key residues by which Jun-Fos complex binds to DNA through hydrogen bonding (Figure 3). To predict the interaction of curcumin derivatives with Jun-Fos complex, natural curcumin derivatives and other known inhibitors of Jun-Fos-DNA complex formation were docked over DNA-binding region (DBR) of Jun-Fos complex, and results were summarized in Table 2.

Amongst all the natural curcumin derivatives docked to Jun-Fos complex curcumin sulphate bound with $\Delta G$ of $-8.20 \mathrm{kcal} / \mathrm{mol}$ and predicted $\mathrm{KI}$ of $976.64 \mathrm{nM}$ followed by cyclocurcumin and demethoxycurcumin which bound with $\Delta G$ of -5.75 and $-5.72 \mathrm{kcal} / \mathrm{mol}$ and predicted $\mathrm{KI}$ of 61.42 
TABLE 1: Synthetic curcumin-based inhibitors of Jun-Fos-DNA complex formation.

\begin{tabular}{|c|c|c|c|c|c|}
\hline Compounds & A & $\mathrm{B}$ & $\mathrm{C}$ & $\mathrm{D}$ & References \\
\hline CHC001 & $\mathrm{H}$ & $\mathrm{OCH}_{3}$ & $\mathrm{H}$ & $\mathrm{H}$ & \multirow{11}{*}[28,29]{} \\
\hline CHC002 & $\mathrm{H}$ & $\mathrm{OCH}_{3}$ & $\mathrm{OCH}_{3}$ & $\mathrm{OCH}_{3}$ & \\
\hline CHC003 & $\mathrm{H}$ & $\mathrm{OCH}_{3}$ & $\mathrm{H}$ & $\mathrm{OCH}_{3}$ & \\
\hline CHC004 & $\mathrm{H}$ & $\mathrm{OCH}_{3}$ & $\mathrm{OCH}_{3}$ & $\mathrm{H}$ & \\
\hline CHC005 & $\mathrm{H}$ & $\mathrm{H}$ & $\mathrm{OCH}_{3}$ & $\mathrm{H}$ & \\
\hline CHC006 & $\mathrm{H}$ & $\mathrm{H}$ & $\mathrm{H}$ & $\mathrm{H}$ & \\
\hline CHC007 & $\mathrm{H}$ & $\mathrm{NO}_{2}$ & $\mathrm{OH}$ & $\mathrm{H}$ & \\
\hline CHC008 & $\mathrm{H}$ & $\mathrm{OH}$ & $\mathrm{H}$ & $\mathrm{H}$ & \\
\hline CHC009 & $\mathrm{H}$ & $\mathrm{NO}_{2}$ & $\mathrm{H}$ & $\mathrm{H}$ & \\
\hline CHC010 & $\mathrm{NO}_{2}$ & $\mathrm{H}$ & $\mathrm{H}$ & $\mathrm{H}$ & \\
\hline CHC011 & $\mathrm{H}$ & $\mathrm{H}$ & $\mathrm{NO}_{2}$ & $\mathrm{H}$ & \\
\hline BJC003 & $\mathrm{H}$ & $\mathrm{H}$ & $\mathrm{CH}_{3}$ & $\mathrm{H}$ & \multirow{3}{*}[28,30]{} \\
\hline BJC004 & $\mathrm{H}$ & $\mathrm{NO}_{2}$ & $\mathrm{CH}_{3}$ & $\mathrm{H}$ & \\
\hline BJC005 & $\mathrm{H}$ & $\mathrm{NO}_{2}$ & $\mathrm{OH}$ & $\mathrm{OCH}_{3}$ & \\
\hline
\end{tabular}

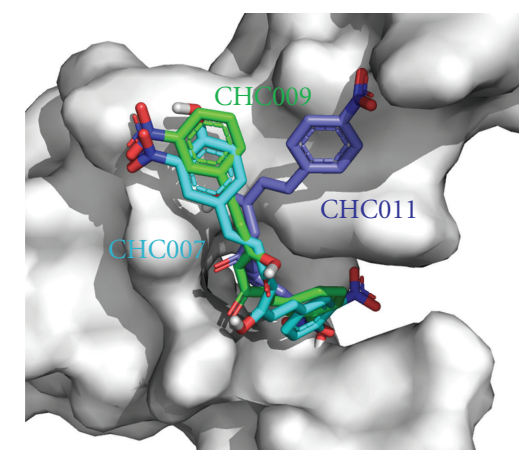

(a)

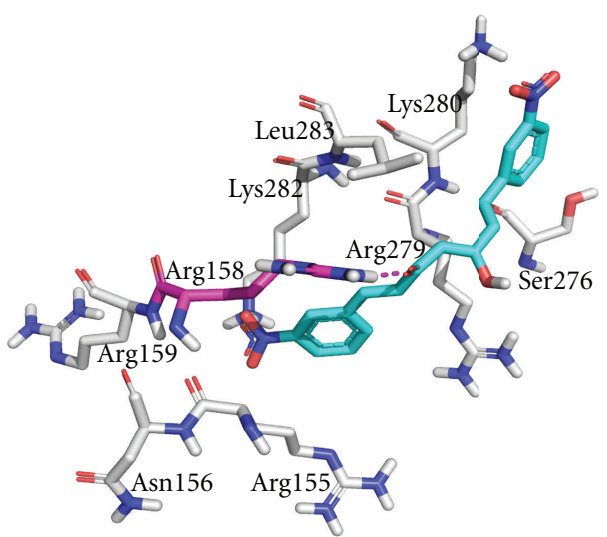

(c)

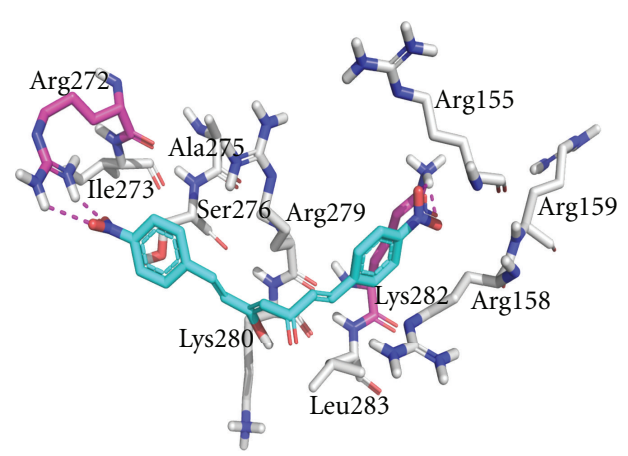

(b)

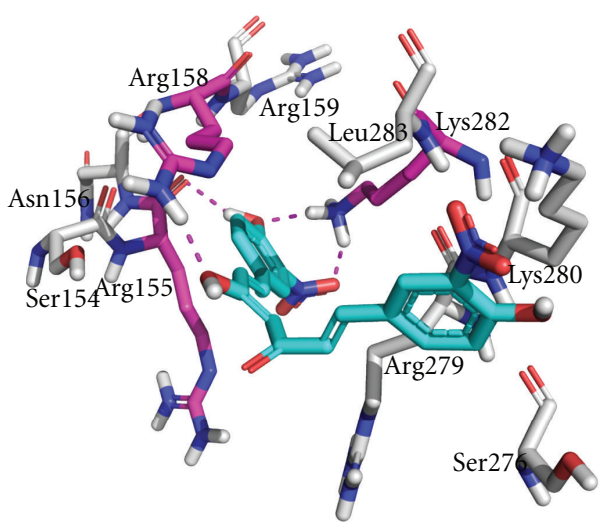

(d)

FIGURE 5: Binding modes of synthetic curcumin-based inhibitors (a) CHC011 (blue), CHC009 (green), and CHC007 (cyan) docked to DBR of Jun-Fos complex; (b) CHC011 (cyan) showing polar contacts with Arg272 and Lys282 (magenta); (c) CHC009 (cyan) showing polar contacts with Arg158 (magenta). (d) CHC007 (cyan) showing polar contacts with Arg155, Arg158, and Lys282 (magenta). 
TABLe 2: Free energy of binding $(\Delta G)$ and predicted inhibition constant (KI) estimated with AutoDock 4.2.1 and interaction of inhibitors with Jun-Fos complex.

\begin{tabular}{|c|c|c|c|c|}
\hline Compounds & $\begin{array}{c}\Delta G \\
(\mathrm{kcal} / \mathrm{mol})\end{array}$ & KI & Putative polar interactions & Hydrophobic residues in $5 \AA$ region \\
\hline T5224\% & -9.96 & $49.64 \mathrm{nM}$ & Arg158, Asn271, Ser278, Arg279, Lys282 & Ala274, Ala275, Leu283 \\
\hline $\mathrm{CHC} 011^{*}$ & -9.59 & $-93.25 \mathrm{nM}$ & Arg272, Lys282 & Ile273, Ala275, Leu283 \\
\hline $\mathrm{CHC} 009^{*}$ & -9.52 & $104.26 \mathrm{nM}$ & $\operatorname{Arg} 158$ & Leu283 \\
\hline $\mathrm{CHC} 007 *$ & -9.15 & $196.96 \mathrm{nM}$ & Arg155, Arg158, Lys282 & Leu283 \\
\hline BJC004* & -9.12 & $207.86 \mathrm{nM}$ & Lys153 & Ala150, Ala151 \\
\hline BJC005* & -8.94 & $277.86 \mathrm{nM}$ & Arg155, Arg158, Lys280, Lys282 & Ala275, Leu283, Ile286 \\
\hline Curcumin sulphate & -8.20 & $976.64 \mathrm{nM}$ & Arg158, Lys280, Lys282 & Leu283 \\
\hline $\mathrm{CHC} 010^{*}$ & -6.73 & $11.59 \mu \mathrm{M}$ & Ser278, Arg279 & Ala274, Ala275 \\
\hline $\mathrm{CHC} 008^{*}$ & -5.86 & $50.65 \mu \mathrm{M}$ & Arg155, Arg158, Ser-276, Lys282 & Leu283 \\
\hline Cyclocurcumin & -5.75 & $61.42 \mu \mathrm{M}$ & $\operatorname{Arg} 155, \operatorname{Arg} 158$ & Ala151, Leu283 \\
\hline $\mathrm{CHC} 003^{*}$ & -5.73 & $62.98 \mu \mathrm{M}$ & Arg158, Arg279, Lys280, Lys282 & Ala275, Leu283 \\
\hline Demethoxycurcumin & -5.72 & $63.86 \mu \mathrm{M}$ & Arg155, Arg158, Ser276, Arg279 & Ala275, Leu283 \\
\hline BJC003* & -5.69 & $67.22 \mu \mathrm{M}$ & $\operatorname{Arg} 158, \operatorname{Arg} 279$ & Leu283 \\
\hline CHCOO4* & -5.66 & $71.36 \mu \mathrm{M}$ & Arg158, Lys280, Lys282 & Leu283 \\
\hline $\mathrm{CHCO06}^{*}$ & -5.45 & $101.79 \mu \mathrm{M}$ & $\operatorname{Arg} 158, \operatorname{Arg} 279$ & Leu283 \\
\hline $\mathrm{CHC} 002 *$ & -5.32 & $125.57 \mu \mathrm{M}$ & Arg155, Arg158, Arg279, Lys280, Lys282 & Ala275, Leu283 \\
\hline Bisdemethoxycurcumin & -5.30 & $130.44 \mu \mathrm{M}$ & $\operatorname{Arg} 158$, Ser276, Arg279 & Leu283 \\
\hline Curcumin (keto) & -5.27 & $136.46 \mu \mathrm{M}$ & $\operatorname{Arg} 158$, Asn271, Arg279, Lys282 & Ala274, Ala275, Leu283 \\
\hline Curcumin (enol) & -5.25 & $141.66 \mu \mathrm{M}$ & Arg158, Ser276, Lys282 & Ala275, Leu283 \\
\hline $\mathrm{CHC} 005^{*}$ & -5.24 & $144.93 \mu \mathrm{M}$ & Arg158 & Leu283 \\
\hline $\mathrm{CHC} 001^{*}$ & -5.19 & $156.49 \mu \mathrm{M}$ & Arg158, Lys282 & Ala275, Leu283, Ile286 \\
\hline$\alpha$-Turmerone & -5.13 & $172.61 \mu \mathrm{M}$ & Lys 282 & Ala150, Ala151, Leu283 \\
\hline$\beta$-Turmerone & -5.05 & $197.55 \mu \mathrm{M}$ & Lys 282 & Ala275, Leu283 \\
\hline Tetrahydrocurcumin & -5.05 & $199.62 \mu \mathrm{M}$ & Arg155, Arg158, Ser276, Arg279 & Leu283 \\
\hline Curcumin glucuronide & -4.61 & $418.23 \mu \mathrm{M}$ & Arg155, Arg158, Arg279, Lys282 & Ala151, Leu283, Ile286 \\
\hline Dihydroguaiaretic acid $\psi$ & -4.43 & $569.58 \mu \mathrm{M}$ & Ser278, Arg279 & Ala151, Ala275, Leu283 \\
\hline Resveratrol $^{\psi}$ & -4.20 & $829.30 \mu \mathrm{M}$ & Ser154, Lys282 & Ala151, Leu283 \\
\hline Hexahydrocurcuminol & -4.08 & $1.02 \mathrm{mM}$ & Arg155, Arg158, Ser276, Lys280, Lys282 & Ala275, Leu283 \\
\hline Hexahydrocurcumin & -4.07 & $1.04 \mathrm{mM}$ & Arg158, Ser276, Arg279 & Ala275, Leu283, Ile286 \\
\hline
\end{tabular}

* Synthetic curcumin-based inhibitors of Jun-Fos-DNA complex formation.

${ }^{\psi}$ Known inhibitors of Jun-Fos-DNA complex formation.

and $63.86 \mu \mathrm{M}$, respectively (Figure $4(\mathrm{a})$ ). The binding mode of curcumin sulphate depicted that sulphate and nearby methoxy group present at one aromatic ring of the molecule were in polar contact range with Lys282; however methoxy group present at the other side formed polar contact with side chain of Lys280 (Figure 4(b)). Keto group present in the linker region was in polar contact range with side chain of Arg158. The binding mode of cyclocurcumin showed that hydroxyl group present at one aromatic ring of the molecule formed polar contact with side chain of Arg155; however at the other side it formed polar contacts with Arg158 (Figure 4(c)). When demethoxycurcumin docked to Jun-Fos complex, hydroxyl and neighboring methoxy group present at one aromatic ring formed polar contact with side chains of Arg155 and Arg279, respectively, while hydroxyl group present at other side of the molecule formed polar contact with side chain of Ser276 (Figure 4(d)). In the linker region of the molecule keto and hydroxyl groups were in polar contact range with Arg158 and Arg279, respectively.

Amongst the synthetic curcumin-based inhibitors CHC011 bound to Jun-Fos complex with $\Delta G$ of $-9.59 \mathrm{kcal} /$ mol and predicted KI of $93.25 \mathrm{nM}$ followed by $\mathrm{CHC} 009$ and $\mathrm{CHCO07}$ which docked with $\Delta G$ of -9.52 and $-9.15 \mathrm{kcal} / \mathrm{mol}$ and predicted $\mathrm{KI}$ of $104.26 \mathrm{nM}$ and $196.96 \mathrm{nM}$, respectively (Figure 5(a)). Similar results were observed in the in vitro studies by Hahm et al. in 2002 [28]. The binding mode studies depicted that $-\mathrm{NO}_{2}$ group present at one aromatic ring of the $\mathrm{CHC} 011$ molecule formed polar contact with side chain of $\operatorname{Arg} 272$ while at the other side of the molecule it interacted with Lys282 (Figure 5(b)). When CHC009 docked to Jun-Fos complex, keto group present in the linker region of the molecule formed polar contact 


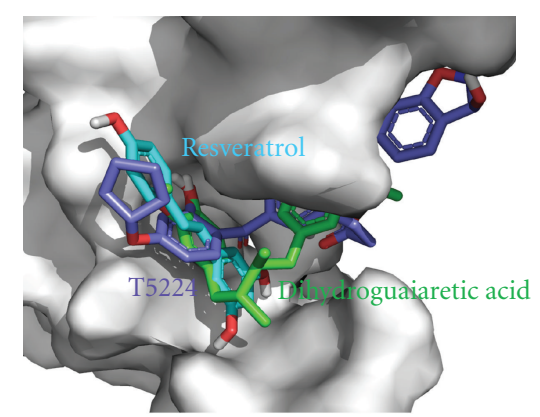

(a)

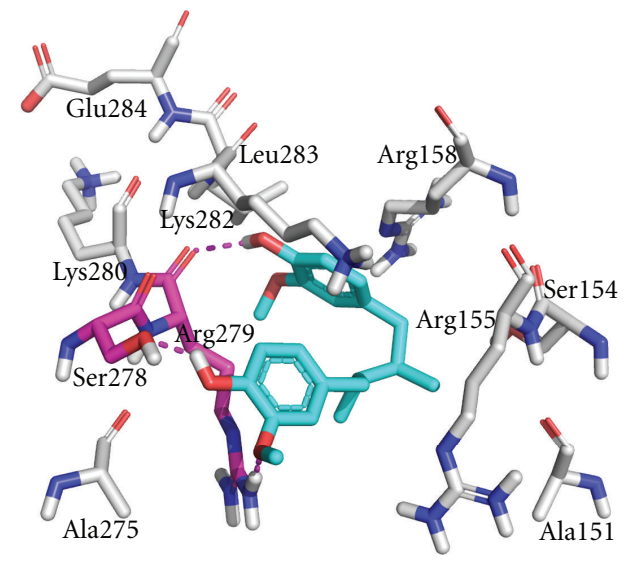

(c)

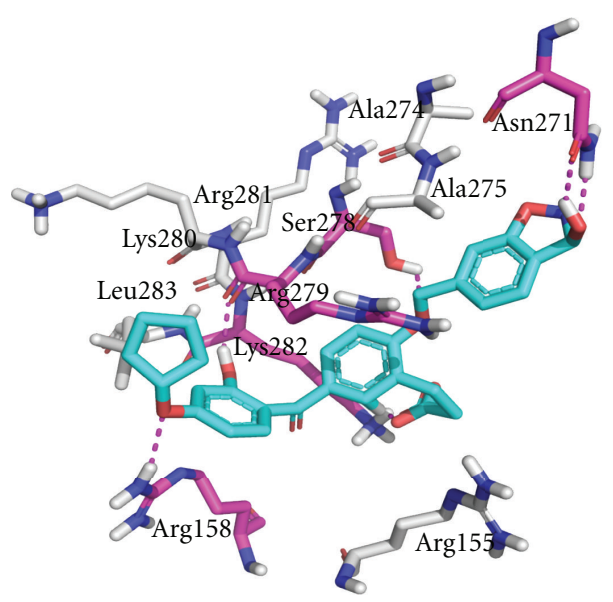

(b)

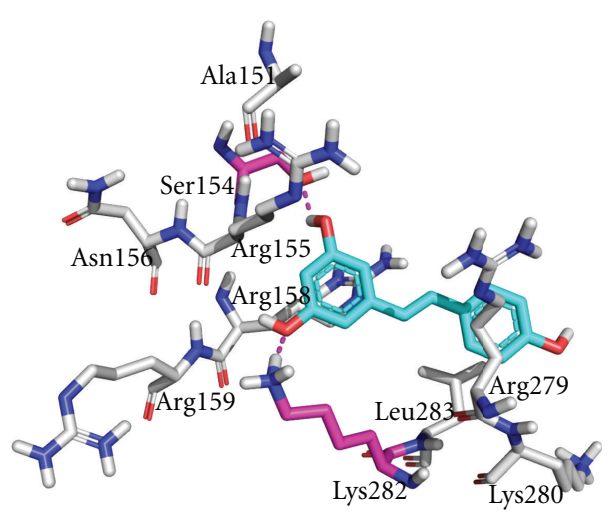

(d)

FIgURE 6: Binding modes of other known inhibitors. (a) T5224 (blue), dihydroguaiaretic acid (green), and resveratrol (cyan) docked to DBR of Jun-Fos complex (b) T5224 (cyan) showing polar contacts with Arg158, Asn271, Ser278, Arg279, and Lys282 (magenta); (c) Dihydroguaiaretic acid (cyan) showing polar contacts with Ser278 and Arg279 (magenta); (d) resveratrol (cyan) showing polar contacts with Ser154 and Lys282 (magenta).

with side chain of Arg158 (Figure 5(c)). Hydroxyl and - $\mathrm{NO}_{2}$ group present at one aromatic ring of the $\mathrm{CHC} 007$ molecule formed polar contacts with backbone of Arg155 and side chain of Lys282, respectively, while the hydroxyl group present in the linker region of the molecule showed polar contact with side chain of Arg158 (Figure 5(d)).

Amongst the other known inhibitors T5224 [3-(5-(4(cyclopentyloxy)-2-hydroxybenzoyl)-2-((3-hydroxybenzo [d]isoxazol-6-yl)methoxy)phenyl)propanoic acid] bound to Jun-Fos complex with $\Delta G$ of $-9.96 \mathrm{kcal} / \mathrm{mol}$ and predicted KI of $49.64 \mathrm{nM}$ followed by dihydroguaiaretic acid and resveratrol which docked with $\Delta G$ of -4.43 and $-4.20 \mathrm{kcal} / \mathrm{mol}$ and predicted KI of 569.58 and $829.30 \mu \mathrm{M}$, respectively (Figure 6(a)). The binding mode studies of T5224 depicted that oxygen atom of cyclopentyloxy group formed polar contact with side chain of Arg158; however nearby hydroxyl group formed polar contact with Arg279. Hydroxyl group of 3-hydroxybenzo [d]isoxazol6-yl)methoxy group formed polar contact with Asn271; however oxygen atom of its methoxy group formed polar contact with Ser278. Acid group of the T5224 molecule was in polar contact range with Lys282 (Figure 6(b)). When docked to Jun-Fos complex neighboring hydroxyl and methoxy groups present at one side of the dihydroguaiaretic acid molecule formed polar contacts with Ser278 and Arg279 respectively, whereas the hydroxyl group present at the other side of the molecule formed polar contact with backbone of Arg279 (Figure 6(c)). When docked to Jun-Fos complex neighboring hydroxyl groups attached to one of the aromatic ring of resveratrol molecule formed polar contacts with Ser 154 and side chain of Lys282, respectively (Figure 6(d)).

We observed that curcumin derivatives form polar contacts preferentially with residues like Arg155, Arg158, Lys276, Arg279, Lys280, and Lys282 when docked to DBR of Jun-Fos complex amongst which Arg155 and Arg158 are the key residues by which Jun-Fos complex binds to DNA. The results suggested that interaction of curcumin derivatives with residues like Arg155 and Arg158 could be the 
possible mechanism by which curcumin derivatives inhibit Jun-Fos-DNA complex formation. Ala151, Ala275, Leu283, and Ile286 were the hydrophobic residues present at binding site contributing to hydrophobic contacts with inhibitor molecules.

\section{Conclusions}

The present molecular docking study provides insights into the inhibition of Jun-Fos-DNA complex formation by curcumin derivatives. The involvement of residues like Arg155, Arg158, Lys276, Lys280, and Lys282 seems to play a key role in binding of curcumin derivatives to Jun-Fos complex through polar contacts which prevents its binding to DNA (AP1 site). Ala151, Ala275, Leu283 and Ile286 were the important hydrophobic residues present at binding site. Most of the curcumin derivatives were predicted to be more potent than inhibitors like resveratrol and dihydroguaiaretic acid. Curcumin sulphate was predicted to be the most potent inhibitor amongst all the natural curcumin derivatives docked.

\section{Acknowledgments}

A. Kumar thanks IITG and MHRD (Government of India) for the fellowship to pursue Ph.D. The authors thank developers of the free softwares used for this study and DBT, Government of India, for providing funds for establishment of Institutional Biotech Hub (BT/04/NE/2009) through which this work was carried out.

\section{References}

[1] R. Eferl and E. F. Wagner, "AP-1: a double-edged sword in tumorigenesis," Nature Reviews Cancer, vol. 3, no. 11, pp. 859$868,2003$.

[2] T. Curran and B. R. Franza, "Fos and jun: the AP-1 connection," Cell, vol. 55, no. 3, pp. 395-397, 1988.

[3] P. F. Johnson and S. L. McKnight, "Eukaryotic transcriptional regulatory proteins," Annual Review of Biochemistry, vol. 58, pp. 799-839, 1989.

[4] P. J. Mitchell and R. Tjian, "Transcriptional regulation in mammalian cells by sequence-specific DNA binding proteins," Science, vol. 245, no. 4916, pp. 371-378, 1989.

[5] W. Lee, P. Mitchell, and R. Tjian, "Purified transcription factor AP-1 interacts with TPA-inducible enhancer elements," Cell, vol. 49, no. 6, pp. 741-752, 1987.

[6] P. Angel, M. Imagawa, R. Chiu et al., "Phorbol ester-inducible genes contain a common cis element recognized by a TPAmodulated trans-acting factor," Cell, vol. 49, no. 6, pp. 729 739, 1987.

[7] P. Angel, K. Hattori, T. Smeal, and M. Karin, "The jun protooncogene is positively autoregulated by its product, Jun/AP-1," Cell, vol. 55, no. 5, pp. 875-885, 1988.

[8] P. Angel and M. Karin, "The role of Jun, Fos and the AP-1 complex in cell-proliferation and transformation," Biochimica et Biophysica Acta, vol. 1072, no. 2-3, pp. 129-157, 1991.

[9] P. Sassone-Corsi and I. M. Verma, "Modulation of c-fos gene transcription by negative and positive cellular factors," Nature, vol. 326, no. 6112, pp. 507-510, 1987.
[10] E. Shaulian and M. Karin, "AP-1 as a regulator of cell life and death," Nature Cell Biology, vol. 4, no. 5, pp. E131-E136, 2002.

[11] H. P. T. Ammon and M. A. Wahl, "Pharmacology of Curcuma longa," Planta Medica, vol. 57, no. 1, pp. 1-7, 1991.

[12] R. C. Srimal and B. N. Dhawan, "Pharmacology of diferuloyl methane (curcumin), a non steroidal anti inflammatory agent," Journal of Pharmacy and Pharmacology, vol. 25, no. 6, pp. 447-452, 1973.

[13] O. P. Sharma, "Antioxidant activity of curcumin and related compounds," Biochemical Pharmacology, vol. 25, no. 15, pp. 1811-1812, 1976.

[14] S. Toda, T. Miyase, and H. Arichi, "Natural antioxidants. III. Antioxidative components isolated from rhizome of Curcuma longa L," Chemical and Pharmaceutical Bulletin, vol. 33, no. 4, pp. 1725-1728, 1985.

[15] R. R. Satoskar, S. J. Shah, and S. G. Shenoy, "Evaluation of anti-inflammatory property of curcumin (diferuloyl methane) in patients with postoperative inflammation," International Journal of Clinical Pharmacology Therapy and Toxicology, vol. 24, no. 12, pp. 651-654, 1986.

[16] A. H. Conney, T. Lysz, T. Ferraro et al., "Inhibitory effect of curcumin and some related dietary compounds on tumor promotion and arachidonic acid metabolism in mouse skin," Advances in Enzyme Regulation, vol. 31, pp. 385-396, 1991.

[17] M. T. Huang, E. E. Deschner, H. L. Newmark, Z. Y. Wang, T. A. Ferraro, and A. H. Conney, "Effect of dietary curcumin and ascorbyl palmitate on azoxymethanol-induced colonic epithelial cell proliferation and focal areas of dysplasia," Cancer Letters, vol. 64, no. 2, pp. 117-121, 1992.

[18] M. T. Huang, Y. R. Lou, W. Ma, H. L. Newmark, K. R. Reuhl, and A. H. Conney, "Inhibitory effects of dietary curcumin on forestomach, duodenal, and colon carcinogenesis in mice," Cancer Research, vol. 54, no. 22, pp. 5841-5847, 1994.

[19] C. V. Rao, A. Rivenson, B. Simi, and B. S. Reddy, "Chemoprevention of colon carcinogenesis by dietary curcumin, a naturally occurring plant phenolic compound," Cancer Research, vol. 55, no. 2, pp. 259-266, 1995.

[20] R. Mohan, J. Sivak, P. Ashton et al., "Curcuminoids inhibit the angiogenic response stimulated by fibroblast growth factor2 , including expression of matrix metalloproteinase gelatinase B," Journal of Biological Chemistry, vol. 275, no. 14, pp. 1040510412, 2000.

[21] T. S. Huang, S. C. Lee, and J. K. Lin, "Suppression of c-Jun/AP1 activation by an inhibitor of tumor promotion in mouse fibroblast cells," Proceedings of the National Academy of Sciences of the United States of America, vol. 88, no. 12, pp. 5292-5296, 1991.

[22] S. S. Han, Y. S. Keum, H. J. Seo, and Y. J. Surh, "Curcumin suppresses activation of NF-kappaB and AP-1 induced by phorbol ester in cultured human promyelocytic leukemia cells," Journal of Biochemistry and Molecular Biology, vol. 35, no. 3, pp. 337-342, 2002.

[23] M. Hergenhahn, U. Soto, A. Weninger et al., "The chemopreventive compound curcumin is an efficient inhibitor of Epstein-Barr virus BZLF1 transcription in Raji DR-LUC cells," Molecular Carcinogenesis, vol. 33, no. 3, pp. 137-145, 2002.

[24] A. Mukhopadhyay, C. Bueso-Ramos, D. Chatterjee, P. Pantazis, and B. B. Aggarwal, "Curcumin downregulates cell survival mechanisms in human prostate cancer cell lines," Oncogene, vol. 20, no. 52, pp. 7597-7609, 2001.

[25] K. Nakamura, Y. Yasunaga, T. Segawa et al., "Curcumin downregulates AR gene expression and activation in prostate cancer cell lines," International Journal of Oncology, vol. 21, no. 4, pp. 825-830, 2002. 
[26] G. Kang, P. J. Kong, Y. J. Yuh et al., "Curcumin suppresses lipopolysaccharide-induced cyclooxygenase- 2 expression by inhibiting activator protein 1 and nuclear factor kappab bindings in BV2 microglial cells," Journal of Pharmacological Sciences, vol. 94, no. 3, pp. 325-328, 2004.

[27] S. Park, D. K. Lee, and C. H. Yang, "Inhibition of fos-junDNA complex formation by dihydroguaiaretic acid and in vitro cytotoxic effects on cancer cells," Cancer Letters, vol. 127, no. 1-2, pp. 23-28, 1998.

[28] E. R. Hahm, G. Cheon, J. Lee, B. Kim, C. Park, and C. H. Yang, "New and known symmetrical curcumin derivatives inhibit the formation of Fos-Jun-DNA complex," Cancer Letters, vol. 184, no. 1, pp. 89-96, 2002.

[29] C. H. Park, J. H. Lee, and C. H. Yang, "Curcumin derivatives inhibit the formation of Jun-Fos-DNA complex independently of their conserved cysteine residues," Journal of Biochemistry and Molecular Biology, vol. 38, no. 4, pp. 474-480, 2005.

[30] H. K. Kim and C. H. Yang, "Synthetic curcumin derivatives inhibit Jun-Fos-DNA complex formation," Bulletin of the Korean Chemical Society, vol. 25, no. 12, pp. 1769-1774, 2004.

[31] J. L. Yap, J. Chauhan, K.-Y. Jung, L. Chen, E. V. Prochownik, and S. Fletcher, "Small-molecule inhibitors of dimeric transcription factors: antagonism of protein-protein and proteinDNA interactions," Medicinal Chemistry Communications, vol. 3, no. 5, pp. 541-551, 2012.

[32] M. F. Sanner, "Python: a programming language for software integration and development," Journal of Molecular Graphics and Modelling, vol. 17, no. 1, pp. 57-61, 1999.

[33] G. M. Morris, D. S. Goodsell, R. S. Halliday et al., "Automated docking using a Lamarckian genetic algorithm and an empirical binding free energy function," Journal of Computational Chemistry, vol. 19, no. 14, pp. 1639-1662, 1998. 


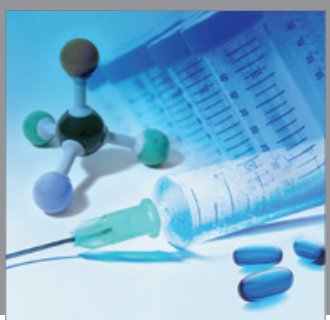

International Journal of

Medicinal Chemistry

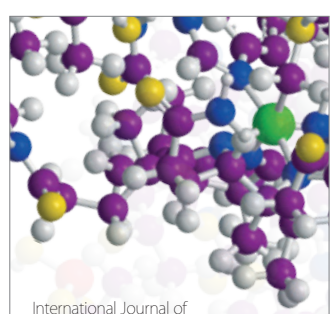

Carbohydrate Chemistry

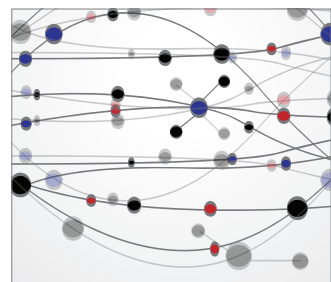

The Scientific World Journal
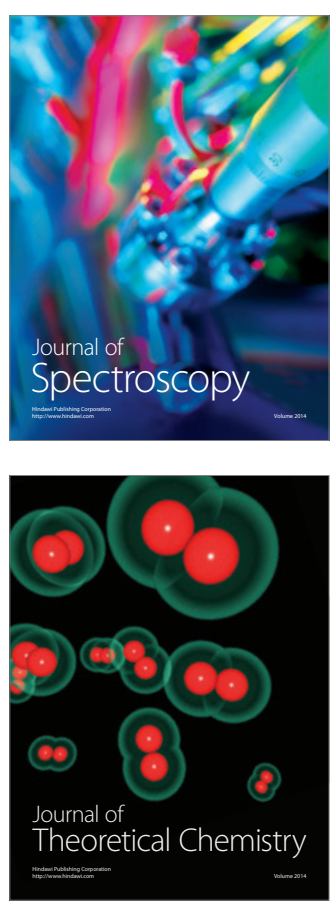
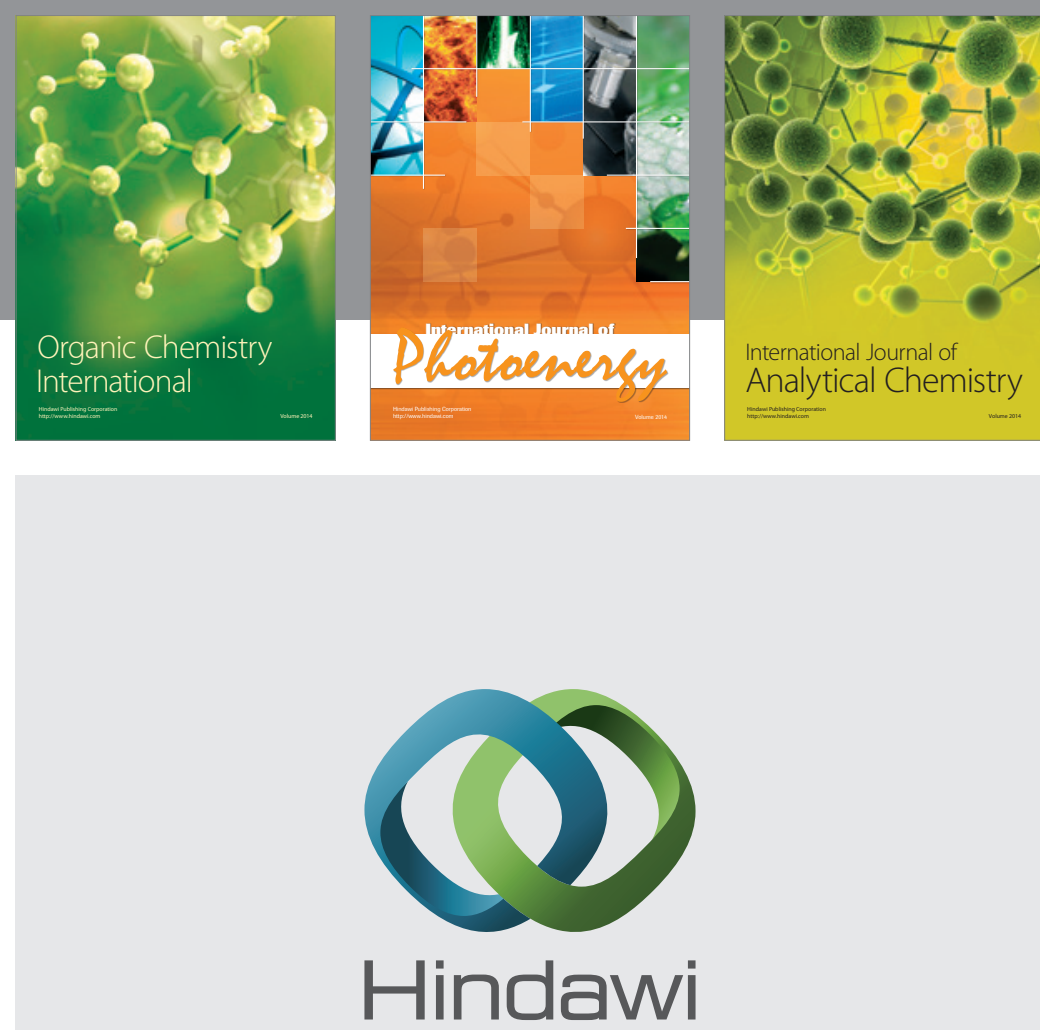

Submit your manuscripts at

http://www.hindawi.com
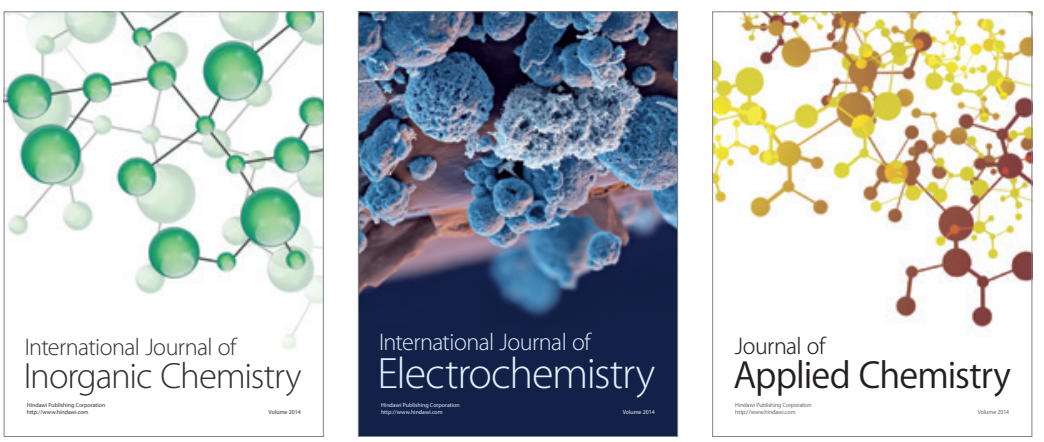

Journal of

Applied Chemistry
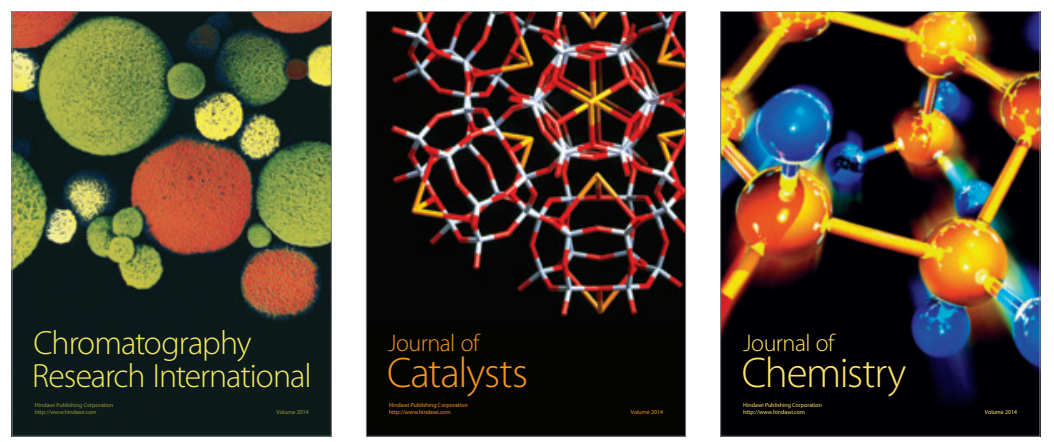
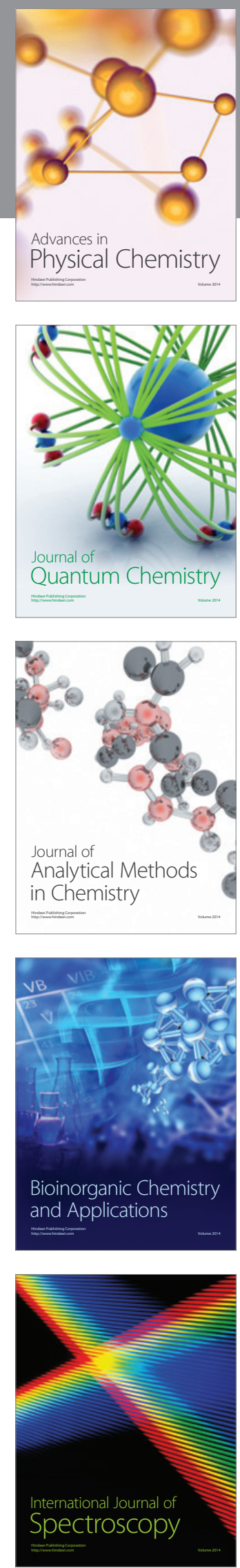